\title{
Relationship between Online Repurchase Intention and E-Satisfaction: Quantitative Research Study Based on Young People in Western Province in Sri Lanka
}

\author{
Anuruddika K. K. R. Jayathilaka \\ University of Sri Jayewardenepuna, Gangodawila, Nugegoda, Sri Lanka \\ Email: anuruddikadec26@gmail.com
}

How to cite this paper: Jayathilaka, A.K.K.R. (2020) Relationship between Online Repurchase Intention and E-Satisfaction: Quantitative Research Study Based on Young People in Western Province in Sri Lanka. Open Access Library Journal, 7: e7007. https://doi.org/10.4236/oalib.1107007

Received: November 16, 2020 Accepted: December 13, 2020

Published: December 16, 2020

Copyright $\odot 2020$ by author(s) and Open Access Library Inc.

This work is licensed under the Creative Commons Attribution International License (CC BY 4.0).

http://creativecommons.org/licenses/by/4.0/

\begin{abstract}
The purpose of this study is to identify the relationship between online repurchase intention and security, trust, ease of use (EOU) and privacy concerns mediated by e-satisfaction. Since there are few studies that explain online repurchase intention in developing countries. This study is based on Sri Lankan online shoppers. A survey method is used for respondents' age between 18 - 32 years. To test the hypothesis of this study, a questionnaire is distributed to participants. The data are analyzed using SPSS software which is used to test the model and the hypothesis. The results showed that ease of use and privacy concerns are the factors that have the greatest impact on consumers' buying behavior. In addition, online satisfaction is important for the group in this study and the results show that it impacts on the relationship between repurchase intention and other factors. This study presents the impact of security, trust, ease of use and privacy concerns on the online repurchase intention of the younger generation. Further, the mediation effect of e-satisfaction is also analyzed.
\end{abstract}

\section{Subject Areas \\ General Management}

\section{Keywords}

Repurchase Intention, Online Repurchase Intention, E-Satisfaction, Sri Lanka 


\section{Introduction}

\subsection{Background of the Study}

Out of 20.91 million total population country has 6.71 million of internet users, which means $32 \%$ have access to internet and using relative services. In Sri Lanka by 2018 the country had maintained an internet penetration growth rate of $7 \%$ annually. According to Kayamu, e-commerce transactions in Sri Lanka are expected to grow by more than $72 \%$ in the near future (Khan, 2017) [1]. It has also shown that Sri Lankan online shoppers are more interested in searching for and buying retail products compared to a country which is yet developing. Also, the Digital marketer website (2020) emphasizes that more and more Sri Lankan consumers search their products online prior to making purchases. Unlike in past now almost everything is connected to online personas in some form, with a huge range of daily interactions taking place in apps, tools and other connected devices, helping to simplify and streamline lives. Accordingly, internet has become the largest virtual aspect that influences the behavior of human beings. Thus, this background is providing a platform to bring out a research study on the relationship between online repurchase intention and e-satisfaction: quantitative research study based on young people in western province in Sri Lanka.

\subsection{The Research Problem/Research Question}

In Sri Lanka, internet users have increased by 7\% annually. But there is lack of researches on online repurchase intention. Most of the researchers have investigated factors affecting online purchase intention (Athapaththu \& Kulathunga, 2018) [2]. There are no any studies on predicting online repurchase intentions with e-satisfaction: a study on Young Generation in Western Part of Sri Lanka. Thus, the research problem for this study will be to discover the different important factors in online shopping. There are five research objectives, namely to examine the relationship between online repurchase intention and security, to examine the relationship between online repurchase intention and privacy concerns, to examine the relationship between online repurchase intention and trust, to examine the relationship between online repurchase intention and ease of use and to analyze the mediation effect of e-satisfaction. The research questions coming along when trying to achieve those objectives are why examine the relationships between online repurchase intention and security? Why examine the relationships between online repurchase intention and privacy concerns? Why examine the relationships between online repurchase intention and trust? Why examine the relationships between online repurchase intention and ease of use? Why analyze the mediation effects of e-satisfaction?

\section{Literature Review}

Online shopping or e-shopping is a form of electronic commerce which allows consumers to directly buy goods or services from a seller over the Internet using 
web browser. This is a fast-growing phenomenon. Online business is considered as a developing among buyers, mainly the younger generation (Trivedi, 2018) [3]. The recognition of online business and online shopping has captured the attention of e-retailers, encouraging researchers to focus on this area (Trivedi, 2018) [3]. Because online shopping is easier and convinient among people. Chua et al., (2006) tells about electronic retailing via the internet or online shopping began in 1994 (Lee, Eze, \& Ndubisi, 2011) [4]. Chua et al., (2006) also state that this new retail concept has attracted the interest of many retailers and merchants as it recognized that online shopping is seen as an alternative channel alongside traditional retail channels such as retail stores (Lee, Eze, \& Ndubisi, 2011) [4]. Pavlou, (2003) specified that in e-commerce, the customer-retailer relationship consists several processes (Athapaththu \& Kulathunga, 2018) [2]. During the initial phase, the customer visits the site and looks for basic information about the product or service they are interested in and, web browsing the product and price comparisons are the main activities engaged by the customer (Athapaththu \& Kulathunga, 2018) [2]. Once he/she selects the product or service, user accounts are created by providing personal information. At this step, cookies, log and data mining tools are typically used for the automatic exchange of information between the customer and the retailer. In the last step, the transaction is completed by providing actual purchase preferences as well as financial and personal information (Athapaththu \& Kulathunga, 2018) [2].

Online purchase intention reflects "the wish of the individual consumer to purchase Internet" and is defined as a circumstance in which an individual Mediation of trust and e-satisfaction intends to purchase from an online marketplace (Trivedi, 2019) [5]. In the context of present study, I have focused on intention instead of behavior. Li \& Hong (2013) [6] revealed that Intention is considered as the best immediate factor in the relationship between attitude and behavior, it is affected by attitude and subjective norms and is appropriate for testing consumer behavior. And also, Chauke \& Dhurup, (2017) [7] defined intention as the degree of customer perception that a particular online shopping behavior will be applied. This implies that behavior is decided by individual intention. Online customer loyalty is a topical issue in the marketing areas ( $\mathrm{Li} \&$ Hong, 2013) [6]. According to Kinnear and Taylor, (1991) Purchase intention is part of consumer behavior related to the consumer attitude and tends to act before a purchase decision is actually made (Yulisetiarini, Subagio, Paramu, \& Irawan, 2017) [8]. Further Raza et al. (2014) mentioned that purchase intention means a condition between the customer and the seller when the customer is ready to enter into an agreement with the seller (Athapaththu \& Kulathunga, 2018) [2]. The purchase intention process begins with product evaluation. Younus, Rasheed, \& Zia (2015) [9] mentioned that Purchase intention is the consumer's preference to purchase the product or service. In other words, purchase intention has another aspect: the consumer will buy a product after evaluation.

Repurchase intention is "the subjective probability that a customer or expe- 
rienced customers will continue to purchase a product from the same online seller" or "buying product/services again from same company" (Trivedi, 2019) [5]. This involves a psychological behavior and one of the main reasons that encourage buyers to have buying products or services again. Aghivirwiati, Giantari, \& Yasa (2018) [10] defined that the repurchase intention is a consumer commitment that was formed after purchased a product or service. Ibsan, Balarabe, \& Jakada, (2016) [11] defined repurchase as the actual behavior of the consumer, which results in the purchase of the same product or service on several occasions. Repurchase intention is the main concern of marketers is to determine customer's purchase intention in a product, thus marketers and economists use the intent to purchase variable in forecasting consumer behavior in the future (Yulisetiarini, Subagio, Paramu, \& Irawan, 2017) [8].

Satisfaction is one of the determinants in achieving the company's customer loyalty goals. Customer satisfaction is the "consumer's fulfillment response," and "a fulfillment, and hence a satisfaction judgment, involves at the minimum two stimuli: an outcome and a comparison referent" (Oliver, 1999, p. 14 as cited in Trivedi \& Yadav, 2018) [3]. Satisfaction is one of the determinants in achieving the company's customer loyalty goals. Therefore, this concept is one of the most studied in marketing (Heriyana, Jasman, Honeyta, \& Chan, 2019) [12]. Extensive researches carried out numerous researchers confirmed that customer satisfaction is one of the most important customer loyalty antecedents (Singh, Sanjith; 2017) [13]. Today competitive marketplace, the most important factor for customer's decision making on purchasing same product or brand again is satisfaction (Sunyansanoa, 2013) [14]. Customers have certain expectations regarding the supply of products and services at the repurchase phase (Chao, Prybutok, \& $\mathrm{Xu}, 2011)$ [15]. This expectation is usually based on experience of others or information obtained through product reviews or word of mouth (Chao, Prybutok, \& Xu, 2011) [15].

The work of Trivedi \& Yaday, (2018) stated that fully understand the purchasing behavior of consumers, it is important for e-business to develop knowledge not only of customer's perception of technology, but also of the significant attributes of technology that can provide high levels of satisfaction in the context of online shopping. Davis (1989) stated that Technology Acceptance model (TAM), based on the theory of reasoned action (TRA), which develops the concept of consumer acceptance of technology and information systems (Trivedi \& Yaday, 2018) [3]. Based on this model, perceived usefulness and perceived ease of use (EOU) are the most important factors in identifying a consumer's intention to adopt technology (Trivedi \& Yaday, 2018) [3]. Teo, Lim, \& Lai, (1999) established that different factors, for example, trust, enjoyment, and social factors are involved in the repurchasing decisions of consumers through the internet and furthermore he mentioned that perceived enjoyment is a personal motivator and it has an insignificant impact on the diversity of internet usage (Trivedi \& Yaday, 2018) [3]. E-business is working to create a pleasant online shopping 
environment to their customers with natural inspiration, which may additionally lead to repurchase intention (Trivedi \& Yaday, 2018) [3]. In this research, trust is considering as one of the factors, along with repurchase intention, that influences e-satisfaction.

\section{Methodology}

The dependent variable is intention to repurchase. While security, trust, ease of use, privacy concern represented the independent variables which are located on the left side of the model. E-satisfaction is a mediation factor for both independent and dependent variables. The conceptual framework (Figure 1) is constructed to identify independent and dependent variable and shows the expected relationship of each variable.

Eight hypothesizes were developed in order to prove the relationships identified in the conceptual framework.

H1: There is a positive relationship between security and online repurchase intention.

H2: There is a positive relationship between trust and online repurchase intention.

H3: There is a positive relationship between EOU and online repurchase intention.

H4: There is a positive relationship between Privacy concerns and online repurchase intention.

H5: E-satisfaction mediates the relationship between security and online repurchase intention.

H6: E-satisfaction mediates the relationship between trust and online repurchase intention.

H7: E-satisfaction mediates the relationship between EOU and online repurchase intention.

H8: E-satisfaction mediates the relationship between Privacy Concerns and online repurchase intention.

An abductive research procedure (moving from observations to results) has been used in this study. In order to examine the factors that may affect the purchasing intentions of Sri Lankan consumers in online shopping, quantitative research will be used to measure variables. The objectives are to examine the relationship between online repurchase intention and security, privacy concerns, trust and ease of use, also, to analyze the mediation effect of e-satisfaction. The first part of the questionnaire is General information. The second part is the main part. There are 22 questions and each item is measured by a five-point $\mathrm{Li}$ kert scale, ranging as " $1=$ strongly agree", " 2 = agree", " $3=$ neutral", " $4=$ disagree", " $5=$ strongly disagree". The research questionnaire was developed on a Likert scale where all responses could be evaluated quantitatively. The base article, 'Predicting online repurchase intentions with e-Satisfaction as mediator' by Trivedi, Y. (2018) was the base principles for the questionnaire design. 


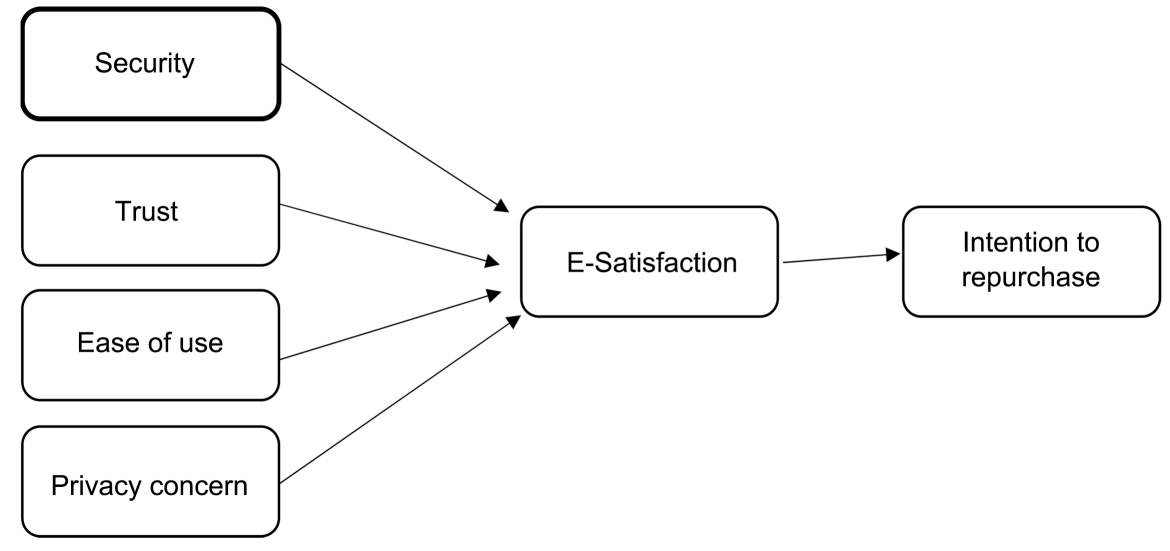

Figure 1. Conceptual framework (Source: Trivedi, 2018) [3].

This study focuses on target population who resides in Sri Lanka. The target respondents were online shoppers aged between 18 - 32 years. These populations were targeted because they are active and young participants in online market place. In this study, non-probability technique was adopted because it is inexpensive, widely used and does not require a large population. This help to reduce the cost of sampling. To be specific Convenience sampling technique is selected in this research. The total number of sampling units used in this research is 158 . A structured questionnaire consists with demographic data, scale of online repurchase intention will be administered to the sample respondents of study through a google form and a manually administered questionnaire. Secondary data of study has gathered from early academic works on similar type of studies published in Emerald insight, Google scholar and few websites.

Data were basically collected by using a survey questionnaire was designed on Google form and sent to subjects through online tools such as, an email and social networking including Viber, Facebook and WhatsApp. In addition, an online approach can be more effective for identifying and reaching online shoppers. This research mainly focuses on consumers with B2C online shopping experience.

\section{Discussion}

Reliability of questioners accesses the quality of measurement procedure which used to collect the data (Table 1). Moreover, Cronbach's alpha test of reliability can be considered as one of the most popular estimates which are used to measure the internal reliability of items in a scale. A questionnaire becomes reliable when Cronbach's Alpha Coefficient is equal or greater than 0.7. Cronbach's alpha of all variables is greater than 0.7 , which indicates, that there is a high inter item consistency reliability, when considering all the variables at once.

According to the Multiple Correlation Test, $\mathrm{p}$-values for all variables are less than the critical P value 0.05 at the $95 \%$ of confidence level. Pearson correlation values indicate that all the variables have positive relationships with the dependent variable because of Pearson values are positive. P values of each Beta coeffi- 
cient of independent variables are used to test the hypotheses. As shown in Table 2, Hypotheses are accepted, if it is $95 \%$ and it is considered as confident interval. To obtain this confident interval, $\mathrm{p}$ value should be equal or less than 0.05. If alternative hypotheses are not supported and $p$ value is less than 0.05 , null hypotheses can be rejected.

Table 1. Reliability statistics 1 (Source: field survey data, 2020).

\begin{tabular}{|c|c|c|c|}
\hline \multicolumn{2}{|c|}{ Security } & \multicolumn{2}{|c|}{ Trust } \\
\hline \multicolumn{2}{|c|}{ Reliability Statistics } & \multicolumn{2}{|c|}{ Reliability Statistics } \\
\hline Cronbach's Alpha & $\mathrm{N}$ of Items & Cronbach's Alpha & $\mathrm{N}$ of Items \\
\hline 0.796 & 2 & 0.870 & 3 \\
\hline \multicolumn{2}{|c|}{ Ease of use } & \multicolumn{2}{|c|}{ Privacy concern } \\
\hline \multicolumn{2}{|c|}{ Reliability Statistics } & \multicolumn{2}{|c|}{ Reliability Statistics } \\
\hline Cronbach's Alpha & $\mathrm{N}$ of Items & Cronbach's Alpha & $\mathrm{N}$ of Items \\
\hline 0.934 & 6 & 0.867 & 3 \\
\hline \multicolumn{2}{|c|}{ 4.3.5 E-satisfaction } & \multicolumn{2}{|c|}{ 4.3.6 Intention to repurchase } \\
\hline \multicolumn{2}{|c|}{ Reliability Statistics } & \multicolumn{2}{|c|}{ Reliability Statistics } \\
\hline Cronbach's Alpha & $\mathrm{N}$ of Items & Cronbach's Alpha & $\mathrm{N}$ of Items \\
\hline 0.922 & 6 & 0.822 & 2 \\
\hline
\end{tabular}

Table 2. Testing of hypotheses 1 (Researcher work).

\begin{tabular}{lccc}
\hline \multicolumn{1}{c}{ Hypothesis } & Beta Coefficient & Significance & Results \\
\hline $\begin{array}{l}\text { H1 Security concerns significantly impact } \\
\text { online repurchase intention. }\end{array}$ & -0.022 & 0.754 & Rejected \\
$\begin{array}{l}\text { H2 Trust significantly impact online } \\
\text { repurchase intention. }\end{array}$ & 0.260 & 0.002 & Accepted \\
$\begin{array}{l}\text { H3 Ease of use significantly impact } \\
\text { online repurchase intention. }\end{array}$ & 0.392 & 0.000 & Accepted \\
$\begin{array}{l}\text { H4 Privacy significantly impact } \\
\text { online repurchase intention. }\end{array}$ & 0.315 & 0.000 & Accepted \\
$\begin{array}{l}\text { H5 E-satisfaction mediates the relationship } \\
\text { between security and repurchase intention. }\end{array}$ & 0.162 & 0.001 & Accepted \\
$\begin{array}{l}\text { H6 E-satisfaction mediates the relationship } \\
\text { between trust and repurchase intention. }\end{array}$ & 0.164 & 0.005 & Accepted \\
$\begin{array}{l}\text { H7 E-satisfaction mediates the relationship } \\
\text { between ease of use and repurchase intention. }\end{array}$ & 0.620 & 0.000 & Accepted \\
$\begin{array}{l}\text { H8 E-satisfaction mediates the relationship } \\
\text { between privacy concern and repurchase } \\
\text { intention. }\end{array}$ & 0.050 & 0.371 & Rejected \\
\hline
\end{tabular}


Regression, Model 1, Independent variables and Intention to repurchase According to the Table 3 Model Summary, R Square in model summary shows the degree to which extent the variance of independent variables is affected to variance of dependent variable. Therefore, $82.6 \%(0.826)$ of the variation of independent variables is affected to intention to purchase.

Regression, Model 2, Independent variables and E-satisfaction

According to the Table 4 Model Summary, R Square in model summary shows that the degrees to which extent the variance of independent variables are affected to variance of dependent variable. Dependent variable means e-Satisfaction. Therefore, $91.6 \%$ (0.916) of the variation of independent variables is affected to e-Satisfaction.

\section{Regression, Model 3, E satisfaction and Intention to repurchase}

According to the Table 5 Model Summary, R Square in model summary shows that the degree to which extent the variance of independent variable is affected to variance of dependent variable. Independent variable means e-Satisfaction. Therefore, $78.8 \%$ (0.788) of the variation of independent variable (e-Satisfaction) is affected intention to purchase.

Since all the $\mathrm{P}$ value in ANOVA tables for the three models are 0.00 and it indicates that these regression models are significant because the $\mathrm{P}$ value are less than 0.05. Therefore, it can be indicated that these models are significant. As well according to the tables of Coefficient, other than security there is significant direct relationship on intention to repurchase from trust, ease of use, privacy concern, security, trust, ease of use, e-satisfaction and intention to purchase since significant value is less than 0.05 .

Table 3. Model summary 1 (Source: field survey data, 2020).

\begin{tabular}{ccccc}
\hline \multicolumn{4}{c}{ Model Summary } \\
\hline Model & $\mathrm{R}$ & R Square & Adjusted R Square & Std. Error of the Estimate \\
\hline 1 & $0.909^{\mathrm{a}}$ & 0.826 & 0.821 & 0.54378 \\
\hline
\end{tabular}

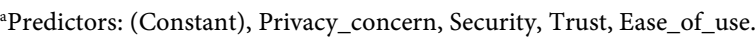

Table 4. Model summary 2 (Source: field survey data, 2020).

\begin{tabular}{ccccc}
\hline \multicolumn{4}{c}{ Model Summary } \\
\hline Model & $\mathrm{R}$ & R Square & Adjusted R Square & Std. Error of the Estimate \\
\hline 1 & $0.957^{\mathrm{a}}$ & 0.916 & 0.913 & 0.34744 \\
\hline
\end{tabular}

apredictors: (Constant), privacy concern, Security, Trust, Ease of use.

Table 5. Model summary 3 (Source: field survey data, 2020).

\begin{tabular}{ccccc}
\hline \multicolumn{4}{c}{ Model Summary } \\
\hline \multirow{2}{*}{ Model } & $\mathrm{R}$ & R Square & Adjusted R Square & Std. Error of the Estimate \\
\hline 1 & $0.888^{\mathrm{a}}$ & 0.788 & 0.787 & 0.59381 \\
\hline
\end{tabular}

apredictors: (Constant), E-satisfaction. 


\section{Conclusions}

This study proved that security, trust, EOU and privacy concerns are the most significant factors to consider in improving consumer repurchase intention. This research also tests the mediation effect of e-satisfaction, and the results claim that e-satisfaction mediates other than privacy concern, security, trust, ease of use have significant relationships. The results of this study showed that hypothesis $\mathrm{H} 1$ was rejected and $\mathrm{H} 2, \mathrm{H} 3$ and $\mathrm{H} 4$ were accepted. In addition, e-satisfaction was identified as a mediator between all the relations tested in this study. The results of the mediation analysis presented that hypotheses $\mathrm{H} 5-\mathrm{H} 7$ were accepted. And $\mathrm{H} 8$ was rejected.

This study was observed that online shopping is not trustworthy and reliable to some customers due to only online payment system and personal privacy. Further online security is a major concern for the consumers particularly in terms of fraud, privacy and hacking. The main disadvantage of any breach of security or confidentiality is the loss of trust and reputation, which can affect customer confidence which can be very damaging for web-based vendors.

For the researchers who are interested in this phenomenon, it is recommended to focus on a different context and conduct the research. As well another recommendation will be to use the same context while analyzing the same topic with a broader level of samples. For the future researchers, there are many gaps and untouched areas that are to be researched.

\section{Conflicts of Interest}

The author declares no conflicts of interest regarding the publication of this paper.

\section{References}

[1] Khan, H. (2017) A Report on e-Commerce Trends in Sri Lanka. http://www.daraz.lk/research

[2] Athapaththu, J. and Kulathunga, K. (2018) Factors Affecting Online Purchase Intention: A Study of Sri Lankan Online Customers. International Journal of Scientific \& Technology Research, 7, 120-128. https://doi.org/10.5539/ibr.v11n10p111

[3] Trivedi, S.K. and Yadav, M. (2018) Predicting Online Repurchase Intentions with e-Satisfaction as Mediator: A Study on Gen Y. Vine, 48, 427-447.

[4] Lee, C.H., Eze, U.C. and Ndubisi, N.O. (2011) Analyzing Key Determinants of Online Repurchase Intentions. Asia Pacific Journal of Marketing and Logistics, 23, 200-221. https://doi.org/10.1108/13555851111120498

[5] Trivedi, S.K. and Yadav, M. (2020) Repurchase Intentions in Y Generation: Mediation of Trust and e-Satisfaction. Marketing Intelligence \& Planning, 38, 401-415. https://www.emerald.com/insight/content/doi/10.1108/MIP-02-2019-0072/full/pdf? Title=repurchase-intentions-in-y-generation-mediation-of-trust-and-esatisfaction

[6] Li, H. and Hong, J. (2013) Factors Influencing Consumers' Online Repurchasing Behavior: A Review and Research Agenda. iBusiness, 5, 161-166.

https://doi.org/10.4236/ib.2013.54020 
[7] Chauke, X.D. and Dhurup, M. (2017) A Generation X Cohort Analysis of E-Shoppers: Satisfaction, Loyalty and Repurchase Intentions in a Developing Country. Journal of Social Sciences, 52, 145-154. https://doi.org/10.1080/09718923.2017.1359908

[8] Yulisetiarini, D., Subagio, A., Paramu, H. and Irawan, B. (2017) Customer Repurchase Intention and Satisfaction in Online Shopping. International Business Management, 11, 215-221.

[9] Younus, S., Rasheed, F. and Zia, A. (2015) Identifying the Factors Affecting Customer Purchase Intention. Global Journal of Management and Business Research: $A$ Administration and Management, 15, 9-14.

[10] Aghivirwiati, G.A., Giantari, K. and Yasa, N. (2018) Effect of Switching Cost on Repurchase Intention with Customer Satisfaction as a Moderating Variable (A Study on Smartphone Products in Indonesia). International Journal of Economics, Commerce and Management, 6, 84-92.

[11] Ibsan, E., Balarabe, F. and Jakada, B. (2016) Customer Satisfaction and Repurchase Intention. Developing Country Study, 6, 96-100.

[12] Heriyana, Jasman, J.M., Honeyta, P.L. and Chan, S. (2019) The Effect of Perceived Risk on Repurchase Intention of Online Shopping Mediated by Customer Satisfaction in Indonesia. KnE Social Sciences, 3, 340-348.

https://doi.org/10.18502/kss.v3i14.4320

[13] Singh, S. (2017) Examining Factors Influencing Customer Loyalty and Repurchase Intentions in Online Shopping: An Indian Perspective. IMR (Indira Management Review), 11, 76-87.

[14] Sunyansanoa, S. (2013) Examining Factors Influencing the Repurchasing Intention of Credence Products: Empirical Evidence from Thailand.

[15] Chao, W., Prybutok, V.R. and Xu, C. (2011) An Integrated Model for Customer Online Repurchase Intention. Journal of Computer Information Systems, 52, 14-23. 